\title{
ASSESSMENT OF HOUSE SPARROW PASSER DOMESTICUS DAMAGE TO SINGLE AND DOUBLE WINTER CULTIVATIONS UNDER FIELD CONDITIONS
}

\section{[132]}

Norhan $^{1^{\star}}$ A. Yacoub, Kassab ${ }^{1}$ A.S.M., Mahgoob ${ }^{1}$ A.E.A. and Ola H. Abdalbar ${ }^{2}$

1- Plant Protection Dept., Fac. of Agric., Ain Shams Univ., P.O. Box 68, Hadayek Shoubra 11241, Cairo, Egypt

2- Agric. Botany Dept., Fac. of Agric., Ain Shams Univ., P.O. Box 68, Hadayek Shoubra 11241, Cairo, Egypt

*Corresponding author: norhanyakoub@agr.asu.edu.eg

Received 15 June, 2019

Accepted 19 June, 2019

\section{ABSTRACT}

The ultimate goal of this study is to find out the most suitable combinations of adjacent crops that reduce house sparrows damage. The experiments were established using single and double combinations of four wintery crops. Namely, soft wheat, hard wheat, sunflower, and barley. The double cultivations were designed by growing varying crops nearby a fixed one crop as follows 1- (soft wheat alone), (soft wheat- near sunflower), ( soft wheat near - barley), and (soft wheat near - hard wheat) 2- (barley alone),(barley- near soft wheat), (barley near - hard wheat), and (barely- near sunflower) 3-(hard wheat alone),( hard wheat- near barley), (hard wheat near - sunflower), and ( hard wheat near - soft wheat).

The experimental results revealed the following; the damage percentage of house sparrows to soft wheat was $25.9 \%$, but when grown nearby sunflower, barley, and hard wheat the soft wheat damage reached $5.9 \%, 25.9 \%$, and $33.3 \%$, respectively. In single cultivation of barley, house sparrows damage was $8.2 \%$, but when grown nearby soft wheat, hard wheat and sunflower, the barley damage reached $13.5 \%, 1.7 \%$ and $1.2 \%$, respectively. Single cultivation of hard wheat house sparrows damage was $0.0 \%$, while when grown adjacent to barley, sunflower, and soft wheat, the hard wheat damage reached $0.0 \%, 0.0 \% 3.8 \%$, respectively. In single cultivation of sunflower, house sparrows damage was $20.2 \%$, while when grown nearby, barley, soft wheat, and hard wheat, the sunflower damage reached $9.5 \%$, $10.2 \%$ and $36.3 \%$, respectively.
Results obtaine from this study revealed the following: 1- sunflower could be grown nearby barley and / or soft wheat, but away from hard wheat; 2- barley could be grown nearby sunflower and /or soft wheat, but away from hard wheat; 3- soft wheat could be grown nearby sunflower, but away from hard wheat; 4- hard wheat could be grown nearby barley or sunflower, but away from soft wheat. These concomitant cultivations can be successfully practiced be small growers to protect their main crops from house sparrows attack naturally and effectively without using any pest control compounds and without any extra costs as well.

Keywords: Passer domesticus, House sparrow, Damage, Crops, Soft wheat, Hard wheat, Barely, sunflower, Adjacent crops.

\section{INTRODUCTION}

House sparrow Passer domesticus is the most common and destructive bird in Egypt that causes huge damage to many standing cereal and sunflower crops (Abdel Gawad et al 2004; ElDananory 2006; Hassan 2008; Abbasy et al 2012).

In Egypt, cereal and sunflower productivities usually is not enough for local consumption (The World Bank, 2017). Reasonably, to increase grain and sunflower yields we need to decrease crop damage by, major pests specially house sparrow in agriculture fields.

Using chemical compounds to get rid of house sparrows is not the proper solution because they have a very high reproduction rate that can fill the 
same space/ fields as long as the three essentials of life and survival are still available (food, shelter and water). At the same time this action can pollute the environment producing adverse effects on biodiversity of birds, locally, regionally and on global scale (Kale et al 2012). Therefore, there is a need to develop alternative eco-friendly solutions to avoid irreversible harm to the environment. In this line, an investigation was conducted by Omar et al (2011). They concluded that, combined cultivations of sunflower and sorghum appeared to be effective in reducing damage of house sparrow. This method is economically and environmentally accepted. However, limited researches were carried out on the combined cultivations of cereal and sunflower crops (Galel 1998; Lopez et al 2011 and Olowe \& Adebimpe 2009).

This study aims to assess the damage caused by house sparrows in single and combined cultivations of soft wheat, hard wheat, barley and sunflower under field conditions. In addition, to evaluate the efficiency of combined cultivations in reducing crop damage which could play an acceptable role in the integrated management of bird populations and reduce their damage to important crops in Egypt.

\section{MATERIALS AND METHODS}

\section{1-Tested site}

This study was conducted in the old land of Agricultural Experimental farm (50 Feddans) of the Faculty of Agriculture; Ain shams University, at Shalakan village, Qalubia Governorate during the winter season of 2016/2017. The experiments were established in the middle of the farm away enough (300 $\mathrm{m}$ at least) from bird nesting sites, human impacts, buildings and field borders. Each experiment was divided into plots $(9 \mathrm{~m} \times 9 \mathrm{~m})$. Each plot treatment was divided into subplots $(3 \mathrm{~m} \times 3 \mathrm{~m})$ was cultivated with one tested plant cultivar.

\section{2- Tested plant cultivars}

The designed experiments were cultivated with soft wheat (Triticum durum var. Sids 12), hard wheat (Triticum turgidum var. Beni-swafe 4) barley (Hordeum vulgare var. Giza126), and sunflower (Hilianthus annus var. Sakha 53). The commercial seeds were obtained from Seed Department of the Ministry of Agriculture, Giza Governorate.

\section{3- Dates of crop planting and harvesting}

These experiments were conducted during winter seasons in 2016/2017. Cereal crops were sown in Nov. of 2016 and were harvested in May of 2017. Sunflower crop was sown in Feb. 2017 and was harvested in May 2017.

\section{4- Agricultural practices}

Plant thinning, weeding, traditional irrigation, and harvesting were carried out manually according to the recommendation of the Egyptian Ministry of Agriculture.

\section{5- Experimental design}

Each two adjacent plots were cultivated with two different crops, while those of the control were cultivated with a single crop, while those of control were cultivated with single crop. Each adjacent two crops as well as their singles were a distance away from each other (about $15 \mathrm{~m}$ ). Entire single and double combinations were arranged as follows:

\section{6- Assessment of house sparrows damage to different crops}

6.1. Assessment of soft wheat damage and when cultivated adjacent to other crops.

These experiments included 4 treatments i.e (soft wheat nearby by sunflower), (soft wheat nearby hard wheat), (soft wheat nearby barley), and (soft wheat alone as control).

\subsection{Assessment of hard wheat damage and when cultivated adjacent to other crops}

These experiments included 4 treatments i.e (hard wheat nearby sunflower), (hard wheat nearby soft wheat), (hard wheat nearby barley), and (soft wheat alone as control).

6.3. Assessment of sunflower damage and when cultivated adjacent to other crops

These experiments included 4 treatments i.e. (sunflower nearby soft wheat), (sunflower nearby hard wheat), (sunflower nearby barley), and (sunflower alone as control). 


\subsection{Assessment of barley damage and when cultivated adjacent to other crops}

These experiments included 4 treatments i.e. (barley nearby soft wheat), (barely nearby hard wheat), (barley nearby sunflower), and (barley alone as control).

\section{Sampling and measurements}

In each replicate (15 subplot) 150 ears or 10 heads were picked up randomly regardless of damage, height, or size. The damage was visually assessed depending on the missing grains or seeds in collected ears or heads. On the whole, 450 ears or 30 heads were taken in each. The percentages of damaged and undamaged crops were calculated according to the equation used by Tolba (1999):

$$
\begin{aligned}
& \% \text { Damage } \\
& =\frac{\text { No.of damaged samples }}{\text { No.of damaged }+ \text { undamaged samples }} \times 100
\end{aligned}
$$

\section{RESULTS AND DISCUSSTION}

\section{Evaluation of house sparrow damage different crop}

The ultimate goal of this study is to detect the most and least damaged crops, when grown in nearby fields. Therefore, several experiments were carried out to evaluate house sparrows damage to following winter crops soft wheat, hard wheat, sunflower and barely.
1.1 Assessment of soft wheat damaged by house sparrows when grown adjacent to other crop species

It is evident from Table (1) and Fig. (1) shown that, soft wheat is highly damaged by house sparrows $(25.9 \%$ damage) when grown singly. On the other hand, minimum damage occurred $(5.9 \%)$ in soft wheat when grown nearby sunflower, while damage reached its minimum (33.3\%) when grown nearby hard wheat, therefore it was realized that, soft wheat could be protected when planted nearby sunflower. On the contrary, it received very low protection from house sparrow damage when planted nearby barely or hard wheat.

Table 1. Percentage of crop damage caused by house sparrow to soft wheat, hard wheat, barley and sunflower under field conditions in winter season of 2017

\begin{tabular}{|l|c|}
\hline Double combination & $\begin{array}{c}\% \text { Soft wheat crop } \\
\text { damage }\end{array}$ \\
\hline (soft wheat - soft wheat) & $25.9 \%$ \\
(soft wheat - barley) & $25.9 \%$ \\
(soft wheat - sunflower) & $5.9 \%$ \\
(soft wheat- hard wheat) & $33.3 \%$ \\
\hline
\end{tabular}

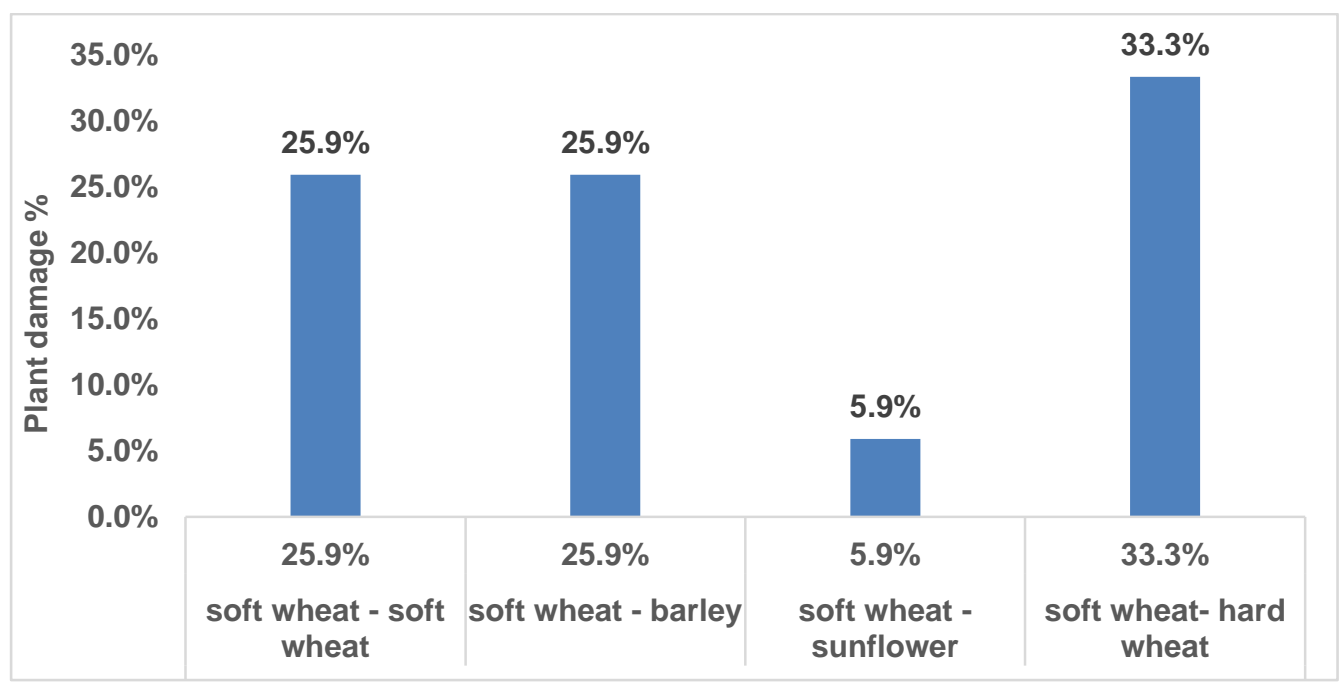

Fig. 1. Percentage of soft wheat damage caused by house sparrow when grown nearby soft wheat, barley, sunflower and hard wheat crops under field conditions in winter season of 2016 /2017. 
1.2. Assessment of barley damaged by house sparrows when grown adjacent to other crops: As shown in Table (2) and Fig. (2), it could be noted that, barley is not a favorable crop for house sparrows since house sparrows damage recorded $8.2 \%$. In this line, barley damage by house sparrows increased as much as $13.5 \%$ when grown nearby soft wheat and decreased as less as $1.2 \%$ and $1.7 \%$ when grown adjacent to sunflower and hard wheat, respectively. This result suggests that, sunflower and hard wheat could play a significant role for protecting barley crop when planted in nearby fields.
Table 2. Percentage damage caused by house sparrow to barley, soft wheat, hard wheat and sunflower under field conditions in winter season of 2017

\begin{tabular}{|l|c|}
\hline Double combination & \% barley crop damage \\
\hline (barley -soft wheat) & $13.5 \%$ \\
(barley - barley) & $8.2 \%$ \\
(barley- sunflower) & $1.2 \%$ \\
(barley - hard wheat) & $1.7 \%$ \\
\hline
\end{tabular}

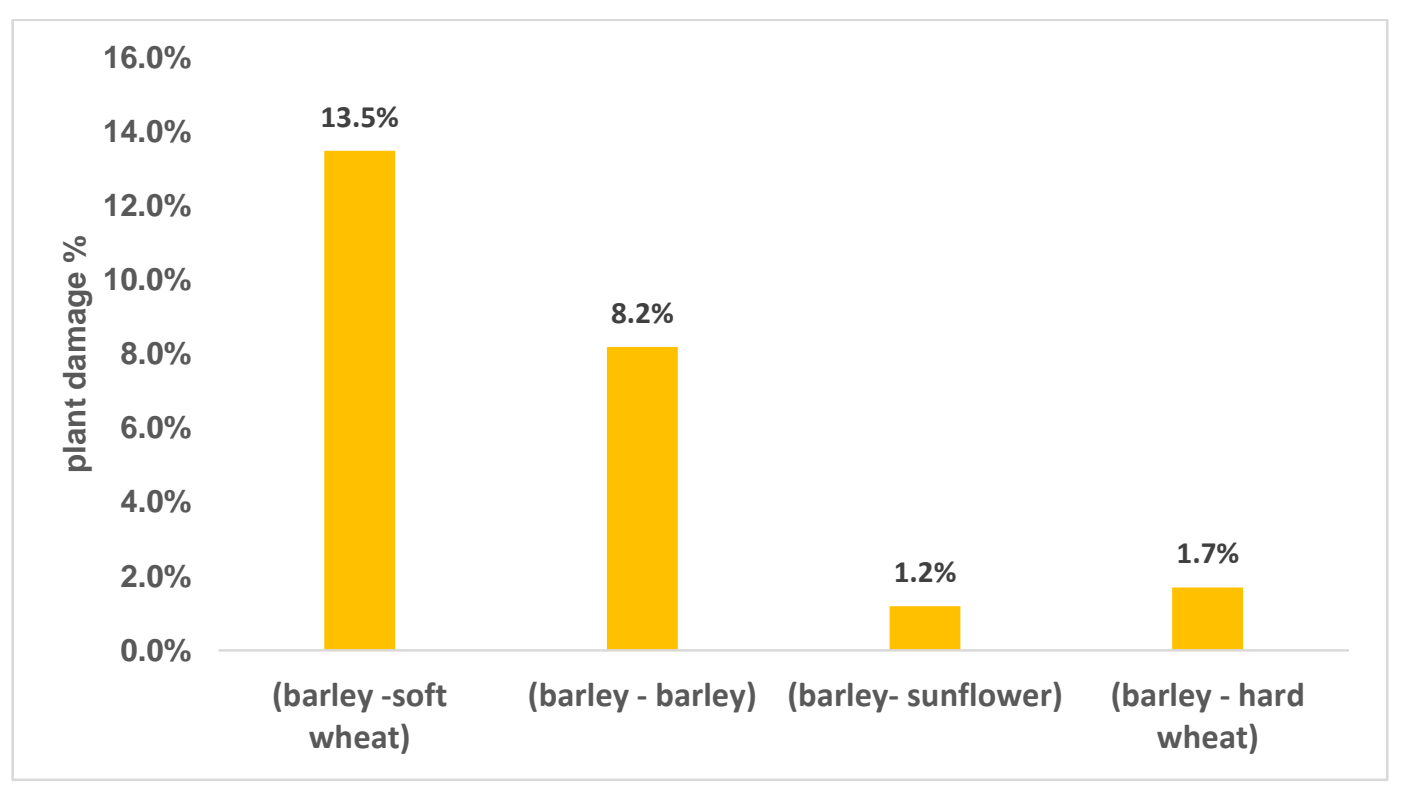

Fig. 2. Percentage of barley damage caused by house sparrow in when grown nearby soft wheat, barley, sunflower and hard wheat under field conditions in winter season of 2017.

\subsection{Assessment of hard wheat damaged by} house sparrows when grown adjacent to other crop

Table (3) and Fig. (3) present damage percentage of house sparrow to hard wheat when grown alone or nearby other tested crops. The results indicated that, hard wheat grown alone was unfavorable to house sparrows since their damage reached nil \%. Moreover, hard wheat did not affected when planted nearby barley, and sunflower $0.0 \%$ damage for both. However, when planted nearby soft wheat, damage to hard wheat reached $3.8 \%$.
Table 3. Percentage of crop damage caused by house sparrow to hard wheat, soft wheat, barley and sunflower under field conditions in winter season of 2017

\begin{tabular}{|l|c|}
\hline \multicolumn{1}{|c|}{ Double combination } & $\begin{array}{c}\% \text { hard wheat crop } \\
\text { damage }\end{array}$ \\
\hline (hard wheat -soft wheat) & $3.8 \%$ \\
(hard wheat - barley) & $0.0 \%$ \\
(Hard wheat - sunflower) & $0.0 \%$ \\
(hard wheat- hard wheat) & $0.0 \%$ \\
\hline
\end{tabular}




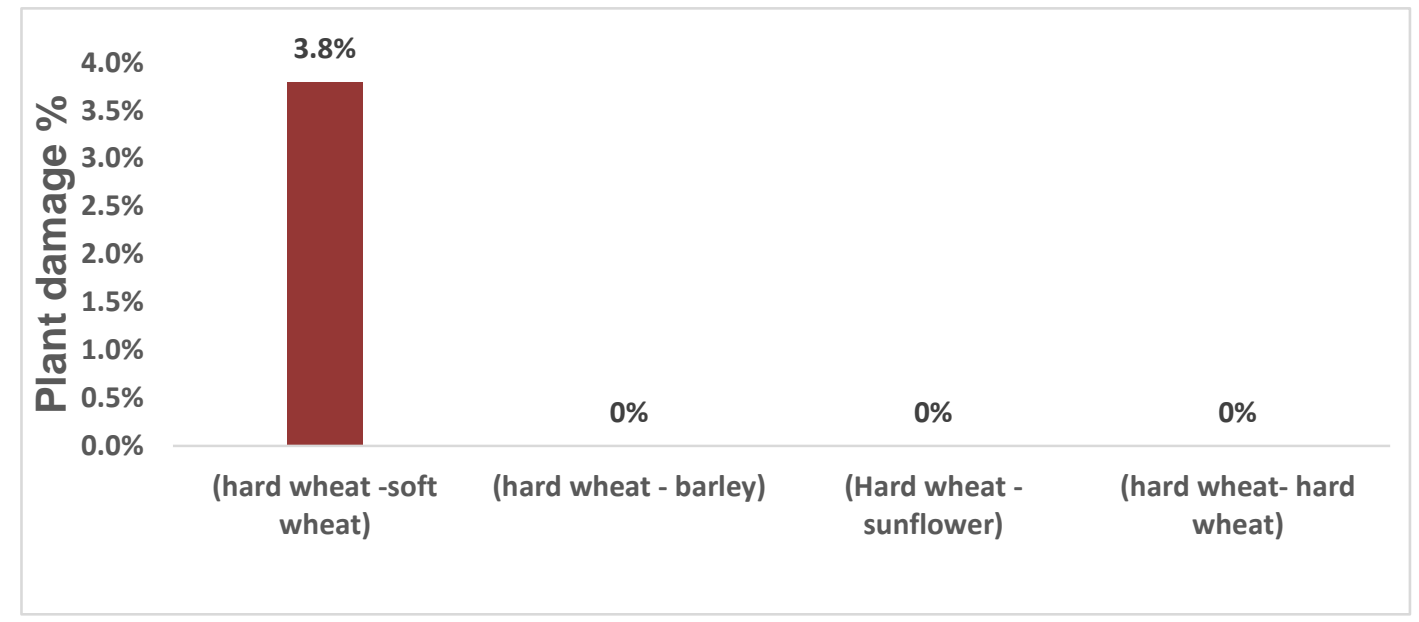

Fig. 3. Percentage of hard wheat damage caused by house sparrow when grown nearby soft wheat, barley, sunflower and hard wheat, crops under field conditions in winter season of 2017

1.4. Assessment of sunflower damage by house sparrows when grown adjacent to other crop species

When Table (4) and Fig. (4) indicated that, sunflower alone was highly damage by house sparrows with a recorded damage $20.2 \%$. Also, it appeared that, sunflower can be affected negatively or positively by other surrounding crops. In this respect, sunflower damaged by house sparrows was depressed when combined with soft wheat and barley recorded damage of $10.2 \%$ and $9.5 \%$, respectively. On the other hand, damage to sunflower elevated up to $36.3 \%$ when planted nearby hard wheat. Thus, sunflower could be protected when planted nearby barley and or soft wheat. On the contrary, sunflower was greatly injured when adjacent to hard wheat.

Table 4. Percentage of crop damage caused by house sparrow to sunflower, soft wheat, hard wheat and barley under field conditions in winter season of 2017

\begin{tabular}{|l|c|}
\hline Double combination & $\begin{array}{c}\% \text { sunflower crop } \\
\text { damage }\end{array}$ \\
\hline (sunflower sunflower) & $20.2 \%$ \\
(sunflower -soft wheat) & $10.2 \%$ \\
(sunflower- barley) & $9.5 \%$ \\
(sunflower- hard wheat & $36.3 \%$ \\
\hline
\end{tabular}

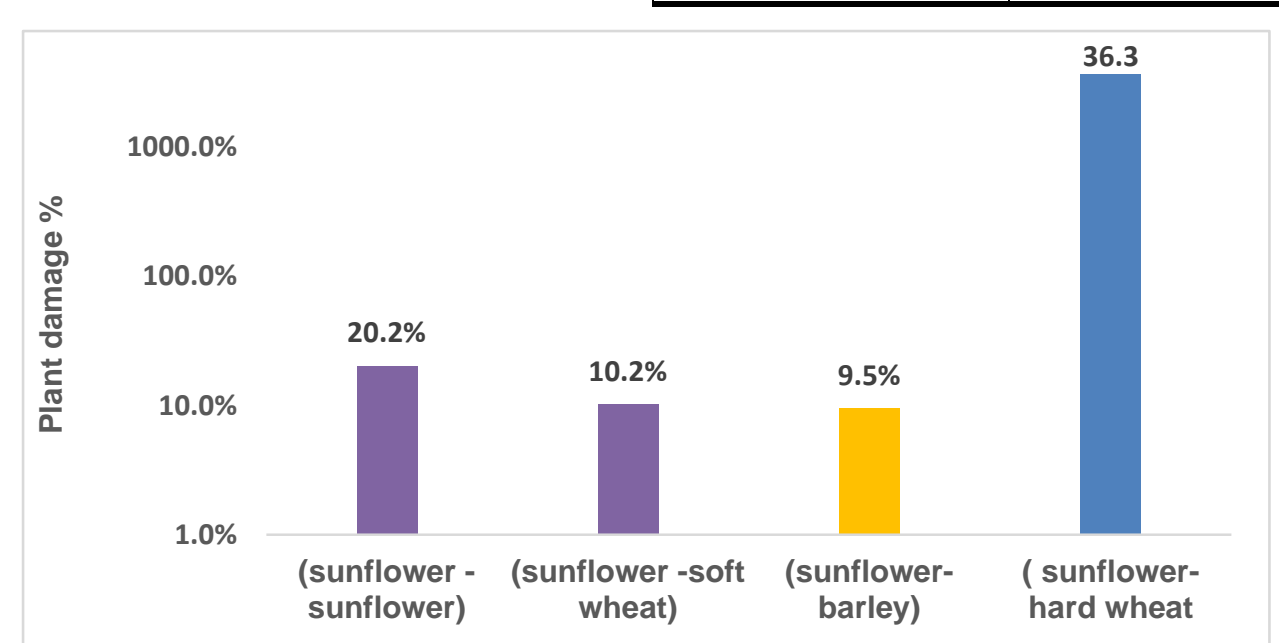

Fig. 4. Percentage of sunflower damage caused by house sparrow when grown nearby sunflower, soft wheat, barley and hard wheat crops under field conditions in winter season of 2017 
As stated above, the present work supports an evidence of dual effects of concomitant cultivations on the damage of arable crops by house sparrows. Similar evidences were reported by Lopez et al (2001) in case of sunflower and maize; Olowe and Adebimpe (2009) and Omar et al (2011) in case of sunflower and sorghum. Phonologically, this concept is accepted when nearby crops were to be timed to coincide with the occurrence of anthesis and maturing stages i.e. sowing two different crops at different time (Lopez et al 2001).

The above obtained results proved that, house sparrows can switch their feeding preference to combined cultivations according to the morphological structure, the ripening stage, the size and nutritional contents of seeds/grains as well as the age and physiological demands of birds. Some workers attributed this behavior to ease of handling by birds, structure of seeds or grains, nutritional materials for breeding progeny, and proteins and fatty acids/ oil requirement for to maximize energy intake (Schluter 1982; Diaz 1994; Schaefer et al 2003 and Hayslette \& Mirarchi, 2001).

As the subject of crop damage is considered, El-Deep (1991), Soliman (1993) and Abbassy et al (2012) indicated that the different monocrops of wheat, barley, broad bean, rice, and maize, exhibited a highly dough damage (5.98\%) followed by milky stage (3.18\%) while mature stage recorded the lowest damage (2.56\%) by house sparrows. Accordingly, the accumulative damage to field crops at harvesting stage was, therefore, the highest level as recorded in the present study. However, this finding lacks the information about the surrounded cultivations. This information has been elucidated in this study.

Therefore, in order to gain a low percentage of crop damage by house sparrows and an optimum crop yield, concomitant cultivations would be recommended as follows:

1- Sunflower could be grown nearby barley and soft wheat, but away from hard wheat.

2- Barley could be grown nearby sunflower or soft wheat, but away from hard wheat.

3- Soft wheat could be grown nearby sunflower, but away from hard wheat.

4- Hard wheat could be grown nearby barley or sunflower, but away from soft wheat.

These concomitant cultivations can be successfully practiced by small growers to protect crops efficiently without any extra costs. Although, the current successful combinations showed to be promising for wider applications, yet other attempts for other protective methods should be planted under future investigations, as well as research on different cultural practices to overcome problems of coordination between neighbor farmers.

\section{REFERNCES}

Abbasy M.R.A., Mostafa M.A., Khattab M.M.D., El-Danasory M.A.M. and Attia M.A.I. 2012. Wild Birds Injurious to Some Field crops at Ismailia Governorate under Field Conditions. J. Plant Prot. and Path., Mansoura Univ., Mansoura, Egypt 3(10), 1067- 1077.

Abd El-gawad K.H., Eraky S.A.M. and Tolba E.F. 2004. Food consumption as a measure of the population density of house sparrow; Passer domesticus niloticus (L.). Workshop on Agricultural development in the Arab Nation, obstacles \& Solution, Assuit, Egypt. pp. 335- 340.

Diaz M. 1994. Variability in seed size selection by granivorous passerines: effects of bird size, bird size variability, and ecological plasticity. Oecologia 99, 1-6.

El-Danasoury M.A.M. 2006. Studies on some wild birds' species in Egypt. Ph.D. Thesis Fac. of Agric., Al-Azhar Univ., Cairo, Egypt. pp. 237238.

El-Deeb H.I.H. 1991. Bird damage to some ripening field crops, under different conditions in Egypt. J. Agric. Res., 18, 835- 841.

Galal A.H. 1998. Effect of different intercropping systems on yield and yield components of maize (Zea mays) and sunflower (Helianthus annuus). Assiut J. of Agric. Sci., 29, 1, 75-85.

Hassan-Eman Kh.K. 2008. Enveronmental problems in relation to Corvidae irds and their management in west and east Delta M.Sc. Thesis Inst. of Nviro. Studies and Res. Ain Shams Univ., Cairo, Egypt, 115 p.

Hayslette S.E. and Mirarchi P.E. 2001. Patterns of food preferences in Mourning Doves. J. of Wildlife Management 65, 816-827.

Kale M., Balfors B., Mörtberg U., Bhattacharya P. and Chakane S. 2012. Damage to agricultural yield due to farmland birds, present repelling techniques and its impacts: an insight from the Indian perspective. J. of Agric. Technology 8(1), 49-62.

Lopez J., Baldini M., Quagliotti L. and Olivieri A.M. 2011. Intercropping Sunflower and Maize in Mozambiqe. HELIA, 24, Nr. 35, pp. 1-10. 
Olowe V.I.O. and Adebimpe O.A. 2009. Intercropping Sunflower with Soyabeans Enhances Total Crop Productivity. Biological Agric. and Horticulture, 26, 365-377.

Omar M.M.A., E.El-bardisy H.A. and AbdelGawad K.H. 2011. Study of Economic Losses Caused by House Sparrow, Passer domesticus niloticus (L.) On Sunflower and Sorghum Crops under the Field Condition. Minia J. of Agric. Res. \& Develop. 31(3), 435-444.

Schaefer H.M., Schmidt B. and Bairlein F. 2003. Discrimination abilities for nutrients: which difference matters for choosy birds and why? Animal Behaviour 65, 531-541.
Schluter D. 1982. Seed and patch selection by galapagos ground finches: relation to foraging efficiency and food supply. Ecology 63, 11061120.

Soliman A.M.A. 1993. Studies on arthropods associated with the harmful birds and their nests at Kafer El-Sheikh Governorate. M.Sc. Thesis, Fac. Agric., Zagazig Univ., Zagazig, Egypt, $115 \mathrm{p}$.

The World Bank 2017. Egypt Country Overview 2017.

https://www.worldbank.org/en/country/egypt.

Tolba E.F.M. 1999. Some ecological aspects on House sparrow attacking various crops in Assiut Governorate. M.Sc. Thesis Fac. of Agric., Assiut Univ., Assiut, Egypt, pp. 91-92. 


\begin{tabular}{|c|c|c|}
\hline & 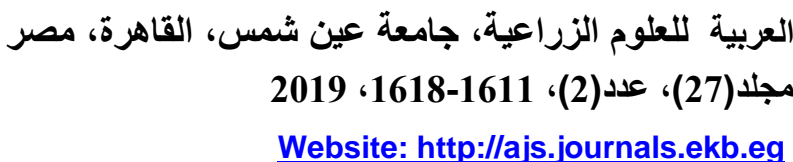 & 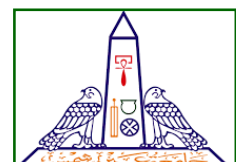 \\
\hline 1618 & & \\
\hline
\end{tabular}

تقدير ضرر العصفور الدوري للمحاصيل الثتوية المنفردة وإلمزدجة تحت الظروف الحقلية

[132]

\author{
نورهان احمد يعقوب1" - عبد الله شحاته محمد كساب1 - احمد عيد عبد المجيد محجوب13 - \\ علا حسين عبد البر 2 \\ 1- قسم وقاية النبات - كلية زراعة - جامعة عين شمس - ص.ب 68- حدائق شبرا 11241 - القاهرة - مصر

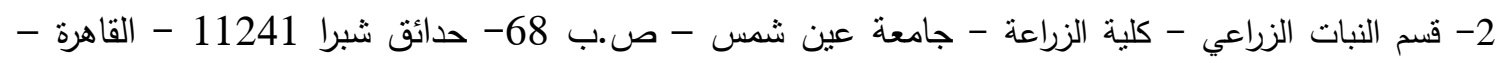

${ }^{*}$ Corresponding author: norhanyakoub@agr.asu.edu.eg

Received 15 June, $2019 \quad$ Accepted 19 June, 2019

في حالة زراعة القمح اللين المفرد كانت نسبة الضرر

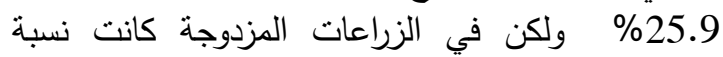

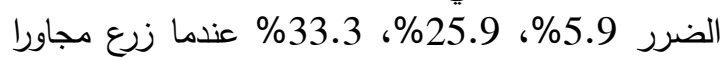

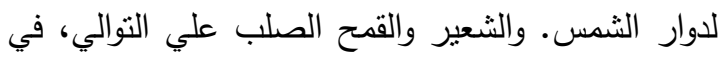

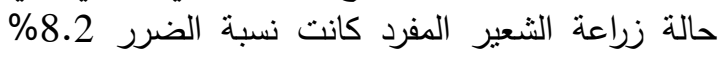

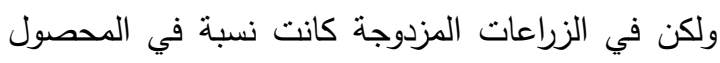

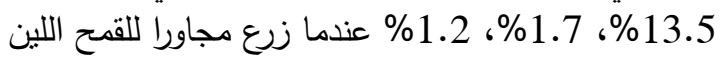

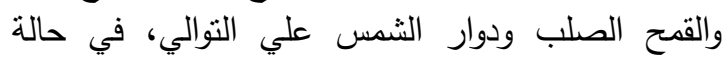

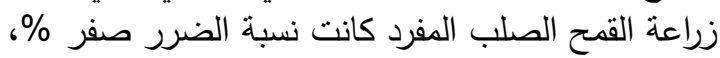

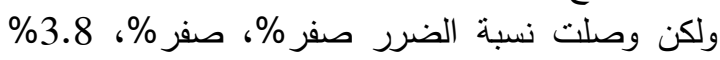
عندما زرع مجاورا للشعبر ودوار الثمس والثمس والقمح اللين

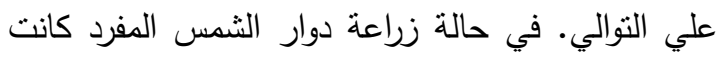

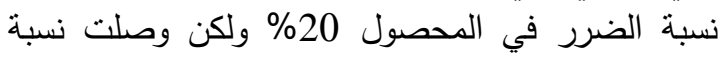

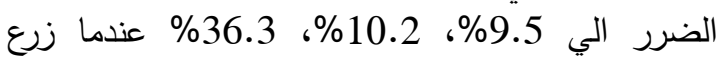

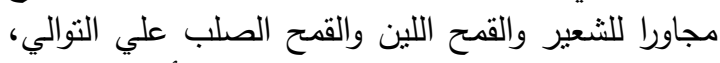

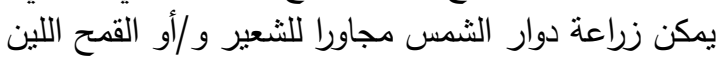

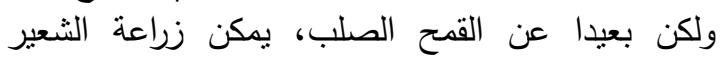

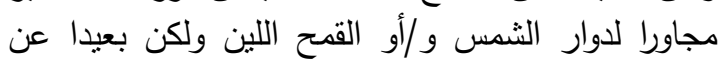

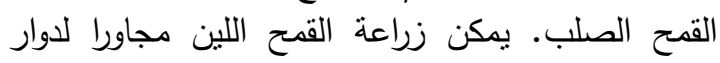

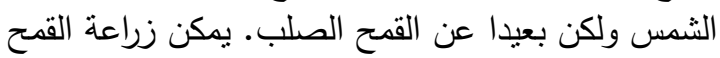
اللين مجاورا للشعير و /أو دوار الثمس ولكن بعن بعيدا عن الثن القمح اللين.

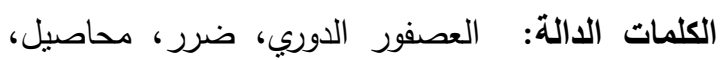

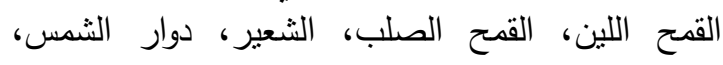

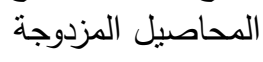

\section{الموجـــــز}

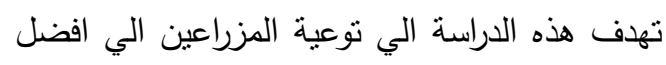

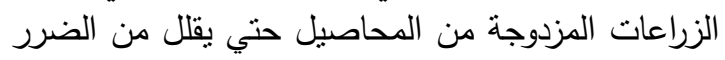
الناتج من مهاجمة العصافير لها.

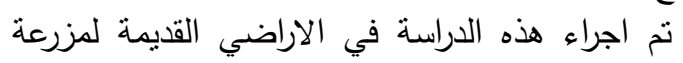

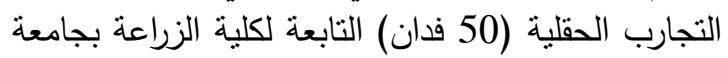
عين شمس والتي تقع في قرية شلقان - محافظة القلوبية

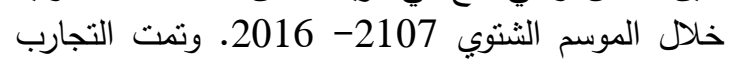
في منتصف المزرعة بعيدا عن اماكن تعشيش العصافير التئري وبعيدا عن حواف الحقل.

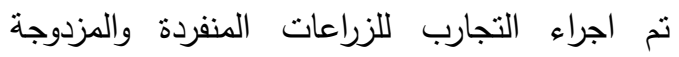

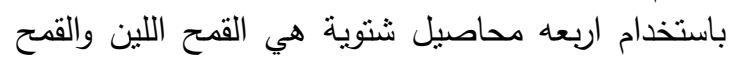

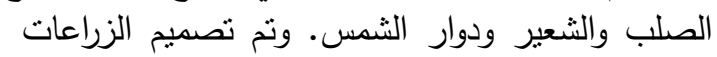

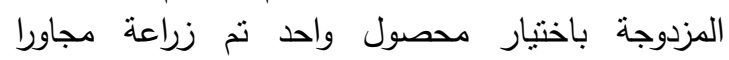

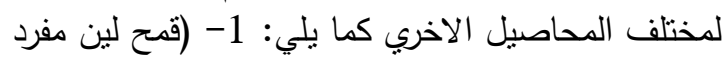

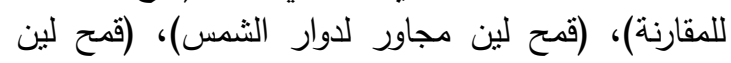

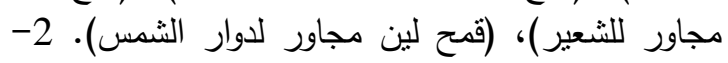

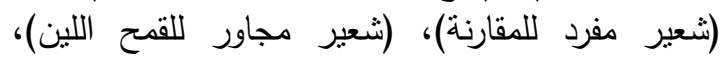

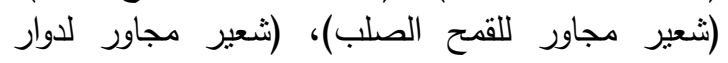

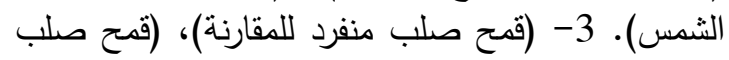

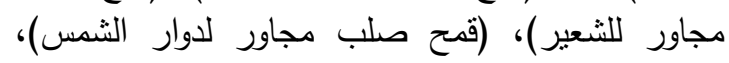

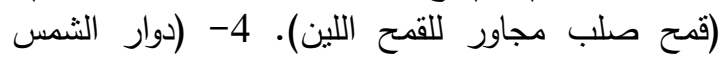

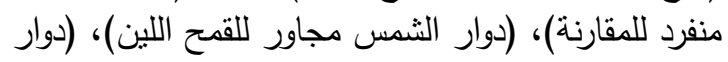

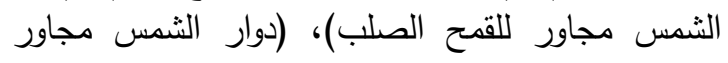
للشعبر) 